3. Dar manny zobowiązujący

do dziękczynien i a Bogu (Mdr 16, 28).

Kolejną lekcję daje Mędrzec Izraelitom i innnym odbiorcom w w. 28, używając zwrotu: „by wiedziano, że w dziękowaniu Tobie trzeba wyprzedzać słońce i wobec Ciebie stawać o świtaniu”. Użyty tu wyraz eucharistia - oznacza „wdzięczność”, "dziękczynienie” i rzadko występuje w LXX, ukazując stosunki międzyludzkie. Być może pod wpływem pobożności hellenistycznej stała się eucharistia potocznym terminem religijnym.

Hagiograf, mówiąc w w. 27, że manna topniała w pierwszych promieniach słońca, natomiast ogień jej nie spalał, podkreśla, że za ten wielki i cudowny dar Jahwe dla Izraela, człowiek zaciągnął wobec Boga dług wdzięczności. Mędrzec nakłada na ludzi obowiązek modlitwy porannej sugerując, ze w dziękowaniu Bogu człowiek winien uprzedzać słońce. Modlitwa poranna wzmocni nas tak, jak wzmacniała Hebrajczyków rankiem zebrana manna, dlatego Hagiograf zachęca do niej czytelników. Człowiek, który się nie modli i za nic nie dziękuje Bogu, jest podobny do rozpływającej się pod działaniem słońca manny. Próżne są wszelkie jego nadzieje. To czego się spodziewa, zniknie ,jak lód zimny i rozpłynie się jak woda bezużyteczna" (w. 29).

Poznań

Ǩs. BOGDAN PONIŻY

\author{
O. Piotr R. Gryziec OFMConv
}

\title{
SPECYFIKA PARAKLEZY W LISTACH ŚW. PAWKA
}

Termin „parakleza” jest spolszczeniem, na wzór autorów niemieckojęzycznych, greckiego rzeczownika paraklēsis: Mimo że jest on wieloznaczny, także w użyciu Pawłowym, to jako termin techniczny, przeważający i zarazem charakterystyczny dla Corpus Paulinum, oznacza pewien szczególny sposób apostolskiego napomnie- 
nia. Terminu tego (niem. Paraklese) jako alternatywnego w stosunku do określenia „pareneza” (gr. parainēsis) użył po raz pierwszy H. Schlier ${ }^{1}$. Zmianę tę argumentował faktem, że rzeczownik pareneza nie występuje w Nowym Testamencie, a więc nie jest kategorią biblijną. Podobny postulat podnosili m.in. E. Schlink ${ }^{2}$. oraz A. Grabner-Haider ${ }^{3}$. Oprócz rzeczownika paraklēsis jeszcze częściej w listach Pawłowych występuje czasownik, od którego się wywodzi parakale $\bar{o}$. Obydwa te terminy występują w Corpus Paulinum 74 razy, parakale $\bar{o} 5$ a, paraklessis 20 razy. Taka statystyka nie odzwierciedla jednak precyzyjnie użycia wspomnianego terminu w listach Pawłowych. Istnieje kilka takich miejsc, w których to samo słowo użyte jest kilkakrotnie w jednym zdaniu lub jednostce tematycznej, zachowując przez cały czas to samo znaczenie ${ }^{4}$. Istotniejsze dla zobrazowania użycia tego terminu przez Pawła jest ustalenie liczby miejsc biblijnych, w których występuje interesujący nas termin (w obydwu formach). Takich miejsc możemy zidentyfikować $56, \mathrm{z}$ tego 33 reprezentuje na pewno sens napominającej zachęty, a 9 innych przynajmniej może zawierać taki aspekt znaczeniowy ${ }^{5}$. Jak z tego wynika zasadniczym zadaniem pawłowej paraklezy jest napomnienie adresatów. W tym celu posługuje się również formułą przejętą $\mathrm{z}$ greckiej tradycji epistolarnej, która rozpoczyna się od słowa parakalo $\overline{0}^{6}$. Napomnienia zawarte $\mathrm{w}$ listach Pawłowych mają jednak swoją własną specyfikę, która nadaje im pewien walor teologiczny. W naszym artykule pominiemy Listy Pasterskie, które co prawda wyszły ze szkoły Pawłowej ${ }^{7}$, ale w któ-

${ }^{1} \mathrm{~W}$ artykule Vom Wesen der apostolischen Ermahnung” opublikowanym po raz pierwszy w r. 1940. Por. tenże, Die Zeit der Kirche, Freiburg ${ }^{4} 1966,74 \mathrm{nn}$. Pareneza jest terminem od dawna przyjętym w polskiej literaturze biblijnej. Wg J. K u d a s i e w i c z a, Biblia, historia, nauka. Rozważania i dyskusje biblijne, Kraków 1986, 427, jest to „zachęta o charakterze moralnym połączona z racjami uzasadniającymi”.

${ }^{2}$ Por. "Gesetz und Paraklese", w: Antwot. Karl Barth zum 70. Gebur$\operatorname{stag}_{3}$ (red. E. W o l ff i in.), Zurich 1956, 326.

${ }_{3}$ W Paraklese und Eschatologie bei Paulus, Munster ${ }^{2} 1985$.

${ }^{4}$ Np. w hymnie 2 Kor 1,3-7 występują obydwie formy: czasownikowa i rzeczownikowa 10 razy, zawsze w sensie pociechy.

${ }^{5}$ Wszystkie powyższe dane na podstawie rozprawy doktorskiej napisanej w KUL: P. G r y z i e c, Parakalein w listach Pawłowych, Lublin 1991 (maszynopis). Inne znaczenia tego terminu to pociecha ( 7 miejsc) prośba (7) oraz "dobre słowo" (1).

${ }^{6} \mathrm{Na}$ temat tej formuły istnieje praca monograficzna: C. J. B j e r k el u n d, Parakalō. Form, Funktion und Sinn der Parakalō-Sätze in den paulinischen Briefen, Oslo 1967.

${ }^{7} \mathrm{Na}$ temat czasu powstania LP i ich pseudonimicznego charakteru por. przede wszystkim komentarz N. B r o x a, Pastoralbriefe, Regensburg ${ }^{\text {prage }} 1989$. 
rych termin parakalein nabrał już zupełnie innego charakteru ${ }^{8}$. Przedstawimy teraz w skrócie cechy specyficzne Pawłowej paraklezy.

a. wymiar chrystologiczny

Parakleza dokonuje się „w Chrystusie” (por. Flp 2,1; 1 Tes 4,1), tzn. nie tylko w imieniu Chrystusa (1 Kor 1,10$)$ i z jego autorytetem ( 2 Kor 5,20), lecz w słowie Apostoła sam Chrystus dochodzi do głosu. Formuły rozpoczynające się od Parakalō. zawierają elementy wskazujące na to, że napomnienie ma być potraktowane jako słowo Pańskie skierowane do wspólnoty (por. 1 Tes 4,1; 2 Tes 3,12; 1 Kor 1,10; Rz 12,1; 15,30), czy też konkretnych osób (Flp 4,2; Flm 9.10).

\section{b. wymiar profetyczny}

Skoro napominające słowo Apostoła jest autentycznym Stowem Pańskim, to ma również charakter prorocki. Zadaniem proroctwa w pierwotnym Kościele było budować, napominać $i$ zachęcać (1 Kor 14,3). Proroctwo polegało na aktualizacji Ewangelii w określonej sytuacji wspólnoty chrześcijań ${ }^{9}$. Także parakleza, biorąc swą podstawę z Ewangelii (por. 1 Tes 2,3) wyrażała konkretne wezwanie do nawrócenia (2 Kor 7,10 ) i życia wiarą (1 Tes 3,2 ; $\mathrm{Rz} 1,12$ ). Tak więc parakleza nie jest synonimem, leez pewnym sposobem i integralną częścią głoszenia Ewangelii.

c. wymiar eklezjalny

Napomnienie dokonuje się wewnątrz wspólnoty Kościoła. Adresaci napomnień nazywani są braćmi (por. 1 Tes 4,1.10b; 1 Kor 1,10; $\mathrm{Rz} 12,1 ; 15,30 ; 16,17)$. Parakleza służy przede wszystkim zbudowaniu wspólnoty (1 Tes 5,11;1 Kor 14,3), co ściśle się łączy z funkcją prorocką. Ma charakter nie tylko „braterski”, ale i „rodzinny” (1 Tes 2,7.11). Oprócz paraklezy wertykalnej (Bóg - Apostoł - wspólnota) wyróżniamy również paraklezę horyzontalną, która polega na wzajemnym zachęcaniu i napominaniu się (1 Tes 4,18; 5,11; 2 Kor 13,11).

${ }^{8} \mathrm{O}$ rożnicach w znaczeniu parakalein w LP por. P. G r y z i e c, Parakalein, 249-250.

${ }^{9}$ Por G. F r i e d r i c h, prophētēs, TWNT VI, 857; O. M i c h e l, Der Brief an die Römer, Göttingen ${ }^{4} 1966,290$. 


\section{d. wymiar charyzmatyczny}

W Liście do Rzymian Apostoł wymienia paraklezę pośród charyzmatów tzw. pneumatycznych, czyli prorockich w szerszym tego słowa znaczeniu ${ }^{10}(\mathrm{Rz} 12,8$; por. $\mathrm{Rz} 1,11 \mathrm{n})$. Chodzi tu o dar przemawiania związany $\mathrm{z}$ inspiracją Ducha Świętego ${ }^{11}$, którego zadaniem jest budujące napominanie i braterska zachęta do postępowania godnego chrześcijanina. Taki charyzmat związany jest $\mathrm{z}$ posługą duszpasterską i często realizowany podczas głoszenia kazań.

\section{e. wymiar moralny}

Treścią napomnień i zachęt firmowanych słowem parakalein jest zawsze postępowanie wynikające $\mathrm{z}$ zasad moralności chrześcijańskiej. Chodzi o takie zasadnicze tematy moralne, jak: „podobanie się Bogu" (1 Tes 4,1), spełnianie Jego woli ( $\mathrm{Rz} 12,1 \mathrm{n})$, postępowanie zgodne z powołaniem chrześcijańskim (1 Tes 2,12; Ef 4,10), posłuszeństwo Chrystusowi (2 Kor 10,1.5n), zachowanie jedności „w Chrystusie” (1 Kor 1,10; Flp 4,2), naśladowanie Apostoła (1 Kor $4,16)$, pojednanie się z Bogiem (2 Kor 5,20).

\section{f. wymiar trynitarny}

Napomnienie „w Chrystusie” oparte na Ewangelii (1 Tes 2,3n) ma swoje ostateczne źródło w samym Bogu: Jakby Bóg przez nas napominal (2 Kor 5,20). Równocześnie, jak już zostało zaznaczone, napomnienie inspirowane jest przez Ducha Świętego (Rz 15,30) i należy do charyzmatów (por. Rz 1,11;12,8). Także prorocki charakter paraklezy wskazuje na jej związek z Duchem Świętym. Wobec tego okazuje się, że parakleza ma wymiar trynitarny,

g. ambiwalencja paraklezy

W myśli teologicznej, opracowanej przez Pawła, nastąpiło połączenie dwu nurtów znaczeniowych terminu parakalein: napomnienia i pociechy. Parakletyczne napomnienie owocuje radością i pocie-

${ }^{10}$ Więcej na ten temat w: P. G r y z i e c, Charyzmat paraklezy, RT 38-39 (1991-2) 85-98. W 1 Kor 14 wydaje się słuszne rozumienie proroctwa, które przejawia się w rozmaitych darach, określonych na wstępie ogólnie jako pneumatika.

${ }^{11}$ Por. F. L a n g, Die Briefe an die Korinther, Göttingen 1986, 202. 
chą nie tylko dla tych, którzy są przedmiotem paraklezy ( 1 Tes 4,18; 2 Kor 1,5nn; 2,8), lecz także tych, którzy przekazują ją w imieniu Chrystusa ( 1 Tes 3,$7 ; 2$ Kor 7,4-13; Rz 1,12). Napomnienie dokonuje się przez apostolskie słowo, natomiast pociecha jest wynikiem działania Bożego, które nie jest bez związku z głoszonym słowem. Paraklezę się głosi, pociechy doznaje (passivum divinum). Obydwa nurty terminologiczne schodzą się $w$ osobie pierwszej przyczyny obydwu działań, jaką jest Bóg. Z drugiej strony uzupełniają się nawzajem, istniejąc w Kościele jako wyraz przeżywanego ciągle napięcia pomiędzy proklamacją królestwa Bożego i jego eschatologicznym dopełnieniem.

\section{h. wymiar historiozbawczy}

Wszystkie zasygnalizowane dotychczas wątki teologiczne zbiegają się w Pawłowej koncepcji dynamicznego słowa Bożego ${ }^{12}$, które działając „w mocy Ducha Świętego (por. 1 Tes 1,5; 1 Kor 2,4) przyczynia się do realizacji zbawienia ( 1 Tes 2,13 ; $\mathrm{Rz} 1,16 ; 10,8 \mathrm{n}$ ) w Kościele, który jest środowiskiem obecności i przekazywania tego słowa.

A zatem nośnikiem paraklezy jest słowo Boże, które uobecniając w Kościele zbawcze działanie Trójcy Świętej, może umacniać w wierze i podnosić na duchu. W paraklezie objawia się moc słowa Boga, które „działa w wierzących” (1 Tes 2,13$)$, dokonując skutecznej realizacji ewangelicznego sposobu życia ${ }^{13}$. Jest domeną działania Ducha Parakleta, który $\mathrm{z}$ jednej strony realizuje w Kościele czas łaski i zbawienia, z drugiej zaś jest permanentnym głosem Boga przypominającego i interpretującego Ewangelię Jezusa i wzywającego do jej zachowania.

Przedstawione w obecnym artykule spostrzeżenia dotyczące paraklezy domagają się konfrontacji ze współczesną eklezjologią i do szukania w niej pewnych implikacji Pawłowych koncepcji. Sobór Watykański II, mówiąc o uczestnictwie kapłanów w potrójnym urzędzie Chrystusa: kapłańskim, prorockim i królewskim (DK 2) stwierdza m.in., że „na mocy władzy duchowej”, która „dana jest dla budowania” (DK 6) winni oni ,zgodnie z wymaganiami nauki i życia chrześcijańskiego" uczyć i upominać powierzony sobie lud według słów: Gloś naukę, nalegaj w porę czy nie w porę, przekonywaj, proś, karć z wszelkq cierpliwościq i naukq (2 Tm 4,2; por DK 6).

${ }^{12}$ Taka koncepcję przedstawia H. M ü $1 \mathrm{l}$ e r, Die Kraft des Wortes Gottes nach den paulinischen Hauptbriefen, Roma 1976.

${ }^{13}$ Por. O. S c h m i t z, parakaleō, TWNT V, 793: „Przez sięgnięcie do zbawczego wydarzenia jako założenia i podstawy, odróżnia się paraklésis od wszelkiego czysto moralnego apelu". 
W powyższym wskazaniu niewątpliwie odnajdujemy echo Pawłowej paraklezy, której stosowanie, mówiąc językiem współczesnej eklezjologii, wiąże się z udziałem w prorockiej funkcji Chrystusa. Zadaniem duszpasterza jest nie tylko przekazywać treść Ewangelii i opartą na niej naukę Kościoła, lecz także zachęcać, apelować, monitować wiernych. Istotne jest, aby współczesny duszpasterz nie zatracił świadomości, że to, co mówi w kościele, winno być słowem Boga (por. $1 \mathrm{P} 4$ 4,11) i że w tej funkcji reprezentuje samego Boga, który przez niego udziela napomnień (por. 2 Kor 5,20). Także odbiorcy paraklezy powinni być otwarci na działanie Ducha Świętego w prorockim słowie napomnienia, które jest zdolne osqdzić pragnienia $i$ myśli serca (por. Hbr 4,12).

Sobór przypomniał również, że wszyscy członkowie Kościoła „wcieleni przez chrzest w Chrystusa” są „na swój sposób uczestnikami kapłańskiego, prorockiego i królewskiego urzędu Chrystusowego" (KK 31; DA 2). Spostrzeżenia zawarte w obecnym artykule wskazują, że takim właśnie uczestnictwem wiernych w prorockim urzędzie Głowy Mistycznego Ciała jest wzajemna parakleza, o której pisze Paweł w swoich listach (1 Tes 4,18; 5,11; 2 Kor 13,11), a która wyraża się $w$ braterskim napominaniu i zachęcie do dobrego „w Chrystusie”.

Kraków

O. PIOTR R. GRYZIEC OFMCONv

\author{
Ks. Stefan Szymik MSF
}

\title{
PODSTAWOWE ASPEKTY ANALIZY NARRACYJNEJ TEKSTU BIBLIJNEGO
}

Pośród współczesnych metod interpretacji tekstu biblijnego na uwagę zasługuje zespół nowych metod analizy literackiej tekstu. Egzegeci coraz częściej odwołują się do nich, gdyż widzą tutaj możliwość pogłębienia i ubogacenia niektórych wyników uzyskanych za pomocą badań historyczno-krytycznych. W ostatnim dokumencie Papieska Komisja Biblijna wymienia trzy podstawowe typy takich 